\title{
Organic Grape Production and Producer Status in Adıyaman Province; Example of Besni District
}

\begin{tabular}{|c|c|}
\hline \multicolumn{2}{|c|}{ 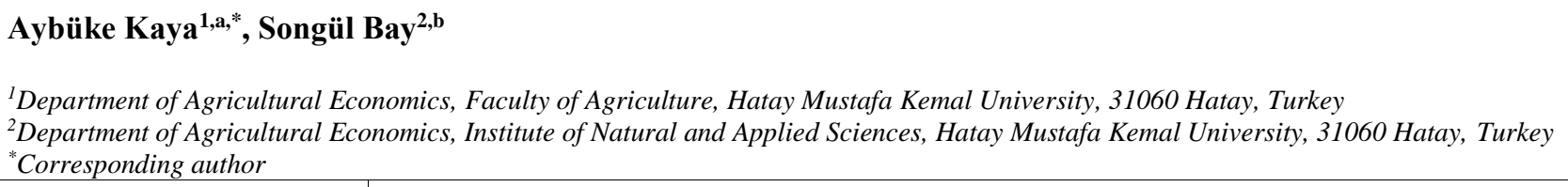 } \\
\hline \multicolumn{2}{|c|}{\begin{tabular}{l|l} 
ARTICLE INFO & A B S TRACT
\end{tabular}} \\
\hline $\begin{array}{l}\text { Keywords: } \\
\text { Grape } \\
\text { Organic farming } \\
\text { Innovation } \\
\text { Environment } \\
\text { Adiyaman Province }\end{array}$ & $\begin{array}{l}\text { This study was carried out to evaluate the socio-economic structure and organic farming activities of } \\
\text { grape producers in Besni. A face-to-face survey was conducted with producers producing organic } \\
\text { grapes. Data were obtained by interviewing a total of } 50 \text { producers. The number of organic products } \\
\text { grown between } 2005 \text { and } 2018 \text { increased from } 205 \text { to } 213 \text { in Turkey. The number of producers } \\
\text { engaged in cultivation in this area has increased more than } 5 \text { times compared to } 2005 \text {. It reached } \\
\text { nearly } 80.000 \text { in } 2018 \text {. The area of organic vegetable production increased from } 203.811 \text { to } 626.884 \\
\text { hectares in Turkey. While the production area increased } 2.5 \text { times, the production amount increased } \\
\text { almost } 4 \text { times. Today, a variety of products in organic vegetable production, planting area, the } \\
\text { number of farmers has increased in Turkey. The findings were obtained education level of the } \\
\text { producers, the number of individuals in the family, record keeping, annual total income, newspaper } \\
\text { reading, grape yield, grape cultivation area, property and rental land, credit usage, weed control, } \\
\text { organic farming knowledge level, organic farming by using variables such as thoughts and grape } \\
\text { variety. There are serious differences between conventional agriculture and organic farming. The } \\
\text { family structure is effective in production activities. It has been determined that the thoughts of } \\
\text { organic farming have changed depending on the age and experience of the producers. Organic grape } \\
\text { producers have turned to organic farming due to their desire to sell their products at higher prices } \\
\text { with state supports. Also, it has been suggested that organic farming is important in terms of the } \\
\text { sustainability of living life all over the world. Increasing producer income and environmental } \\
\text { awareness are among the main reasons for the transition to organic farming. }\end{array}$ \\
\hline
\end{tabular}

Türk Tarım - Gıda Bilim ve Teknoloji Dergisi, 8(9): 1988-1993, 2020

\section{Adıyaman İlinde Organik Üzüm Üretimi ve Üretici Yapısı; Besni İlçesi Örneği}

\begin{tabular}{|c|c|}
\hline M A K A L E B İ L G İ S İ & Ö Z \\
\hline $\begin{array}{l}\text { Anahtar Kelimeler: } \\
\text { Üzüm } \\
\text { Organik tarım } \\
\text { Yenilik } \\
\text { Çevre } \\
\text { Adıyaman İli }\end{array}$ & 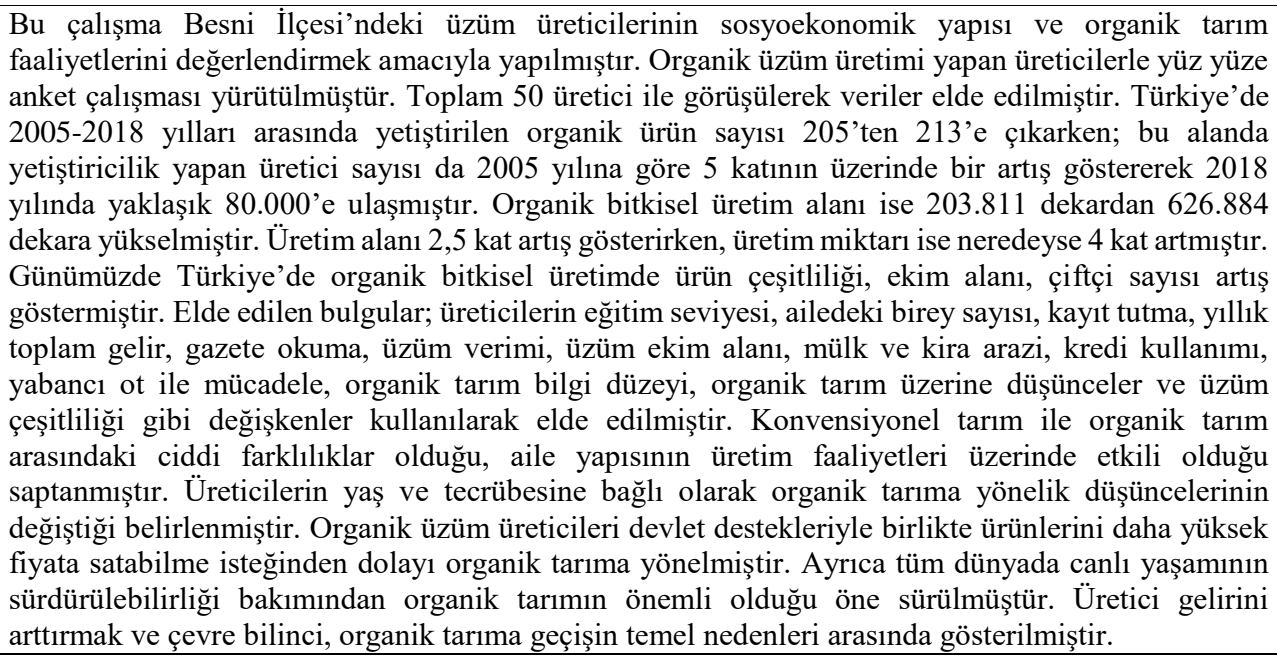 \\
\hline
\end{tabular}




\section{Introduction}

The rapidly increasing world population brings with it the demand for foodstuffs (vegetable and animal). However, it is impossible to increase the amount of land required for the current production. For this reason, production is tried to be increased with yield obtained from the unit area. However, as well as increasing productivity is important, the health of humans and other living things is also important.

Today, practices carried out in agricultural activities disrupt the natural balance. It poses a life-threatening life that can reach all living things besides human beings through the food chain (Turhan, 2005; Ayla and Altıntaş, 2017). It is applied in agriculture, activities such as good agricultural practices and organic farming to reduce environmental damage (Ak, 2004; Merdan, 2014). However, it should not be considered that combating disease and pests, fertilization is not done in these applications (Kirımhan, 2005). In Turkey, both biological and genetic diversity that is suitable for the organic farming system (Kizilaslan and Olgun, 2012).

According to 2016 data in the world, it is known that organic production is made by 2.7 million producers in an area of 57.8 million hectares in 178 countries (Willer and Lernoud (Ed.), 2018). Organic farming has emerged since the mid-1980s, under the leadership of European organic farming companies in Turkey. It started with the production of dried grapes, dried figs, dried apricots, and hazelnuts for export with the contracted agriculture system. The first organic raisin production project was initiated in 1986. This was followed by the organic fig project in 1987. In the following years, the variety of products has increased in this regard. Production and export have started on hard and dried fruits, frozen fruits and vegetables, fresh fruits and vegetables, spices, and legumes. It also gained rapidness in rose water, rose oil, olive oil, cotton, and textile products. The improvement in organic cotton production has also increased in the organic textile sector (Anonymous, 2019). Consumers' concerns about food safety, the effects of conventional agriculture on the environment, regulated policies, and incentives have drawn attention to organic farming production. However, there are differences between the production costs, cost items, and profitability of traditional and organic farming practices (Yercan, 2003).

Grape is a Vitis genus plant of the vine family (Vitaceae). It is one of the most widespread cultivars in the world due to reasons such as being suitable for cultivation in Anatolia, which is a part of its homeland and is not very selective in terms of climate and soil requirements, being easy to reproduce and being consumed in a variety of ways (Taşkaya, 2005; Özbağ, 2010). Also, grapes are among the products with high added value that can be consumed in the form of a table, wine, dried, vinegar, molasses, confectionery, fruit juice, and other products. About $40 \%$ of the grapes grown dried evaluated, $25 \%$ is consumed as a table in Turkey. Also, $20 \%$ of the grapes produced are evaluated by making vinegar, molasses, and fruit pulp. Approximately $15 \%$ of the production is used in the alcoholic beverage industry. However, approximately $90 \%$ of the product is used in wine production in western countries (Duran, 2003).
Organic grape production areas are increasing in the world. Countries such as Spain, Italy, France, and China have the largest share in 2014 among organic grape growing countries. Turkey is located on the fifth-largest after those countries. According to data from 2014, 21.7 thousand tons of organic fresh grape in Turkey, while production was 5.6 thousand tons of organic dried grape. While Manisa comes first among the provinces with the highest organic grape production; continues as İzmir, Mersin, Niğde, Tekirdağ, and Çanakkale respectively. This value corresponds to $61.7 \%$ of the total organic grapes was produced in Turkey. It corresponds to $94 \%$ of organic dried grape (Mısır and Pezikoğlu, 2016).

This study covers the production of grapes in Besni District of Adiyaman, one of the important grape producer provinces of the Southeast Anatolia Region. It was made to reveal the socio-economic status of organic grapeproducing enterprises and their thoughts on organic farming.

\section{Material and Method}

The main material of the research consists of the data obtained from the surveys conducted with organic grape producers and the observations of the researcher in Besni District of Adryaman Province. Also, secondary data were used on the subject received from the database Turkey Statistical Institute (TURKSTAT). The change between these data analyzed over the years has been put forward by a simple index method. In the scope of the research, Besni District Agricultural Directorate data was used to collect the necessary data.

Besni District Agriculture Directorate was used to collect the necessary data within the scope of the research. It was examined through the farmers' lists that received organic farming support and cultivated grapes. According to these lists, a survey was conducted in the villages of Besni district using the full count method. In this context, 50 producers producing certified organic grapes were interviewed face to face. In this study conducted with organic grape producers of Besni District, which was determined as the target audience, the minimum level of producers could not be reached.

The survey of the research was applied in the summer of 2017. The survey forms prepared within the scope of the research were pre-tested. After the necessary arrangements were made, data were collected from the research area. Field observations and group interviews were also used to develop and support the data set. The methods to be used in data evaluation were chosen for the research. The analysis of the study was evaluated using the SPSS package program. Categorical variables in the form of frequency and percentage ratio; numerical variables are given as average.

\section{Results and Discussion}

\section{General Information about Research Area}

Besni district, which constitutes the research area, has a characteristic between the Mediterranean climate and the eastern continental climate. With the construction of the 
Atatürk Dam, a noticeable difference occurred in the climate of the district. In particular, a significant increase was observed in the amount of moisture and precipitation (Anonymous, 2018). The region has a total area of $1,327,000 \mathrm{da}$, together with 490,986 fields, 228,803 vineyards, and gardens. More than half of this area is used as agricultural land (54\%). During the last 20 years, significant changes have occurred in the district's crop pattern and production style. It is known that a large amount of dry farming system was applied in crop production before the 1980s. Today, it is a region where approximately $30-32 \%$ irrigated agriculture system is applied (Anonymous, 2017a).

According to the Statistics Data Network (IVA) data, total field crop production in Besni was 187,023,000 tons, 28,707 tons of vegetable production, and 3,385,615 tons of vineyard and garden production in 2017. Total grapes (vineyard) produced 17,916 tons of planting area of 30.200 decares. There are 5,575 producers in the Besni District Agricultural Directorate connected to the farmer registration system. While the number of farmers engaged in organic farming in the field of research was 20 producers in 2015 , it increased to 370 producers in 2016 . The number of producers growing grapes is 676 in total. While Adiyaman is 983 producers across the province, Besni district realizes the majority of production alone. In 2016, $1,727,301.66$ was paid to the producers registered for organic farming support (Anonymous, 2017b).

According to the data on grape production between the years 2006-2016 the grape cultivation area increased from
13,500 decares to 23,910 decares in Besni district. Between the specified years, the production amount increased from 3,500 tons to 10,916 tons and exceeded 3 times. Besides, the grape yield has increased significantly from $259 \mathrm{~kg} / \mathrm{da}$ to $457 \mathrm{~kg} / \mathrm{da}$. By years, the planting area of Besni tableseed grape production has increased steadily. However, fluctuations are observed in production and yield values (Table 1).

The planting area for the production of dried-grape grapes in Besni district increased from 5,000 decares to 6,100 decares between 2006 and 2016. The amount of production increased significantly from 1,050 tons to 5,490 tons between the specified years. The grape yield was realized from $210 \mathrm{~kg} / \mathrm{da}$ to $900 \mathrm{~kg} / \mathrm{da}$. It is seen that the increase in the production of Dried-seed grape in the district is mostly due to the increase in yield (Table 2).

Today, organic product variety, production area, and the number of farmers have increased in Turkey. Due to all these factors, there is a serious increase in the production amount of organic products. The number of organic products grown according to the Turkey Statistical Institute data has increased from 205 to 213 in the years 2005-2018. The number of producers engaged in cultivation in this area has increased more than 5 times compared to 2005. It reached nearly 80.000 in 2018 . The area of organic vegetable production increased from 203.811 to 626.884 hectares in Turkey. While the production area increased 2.5 times, the production amount increased almost 4 times (Table 3).

Table 1. Table-seed grape production in Besni district $(2006=100)$

\begin{tabular}{c|cccccc}
\hline Year & Area (da) & Index & Production (ton) & Index & Yield (kg/da) & Index \\
\hline 2006 & 13,500 & 100 & 3,500 & 100 & 259 & 100 \\
2007 & 21,500 & 159 & 6,675 & 191 & 310 & 120 \\
2008 & 22,300 & 165 & 7,550 & 216 & 339 & 131 \\
2009 & 22,800 & 169 & 7,650 & 219 & 336 & 130 \\
2010 & 22,718 & 168 & 13,903 & 397 & 612 & 236 \\
2011 & 22,718 & 168 & 14,994 & 428 & 660 & 255 \\
2012 & 22,718 & 168 & 14,994 & 428 & 660 & 255 \\
2013 & 22,760 & 169 & 15,402 & 440 & 677 & 261 \\
2014 & 22,760 & 169 & 17,070 & 488 & 377 & 555 \\
2015 & 23,760 & 176 & 13,187 & 312 & 457 & 290 \\
2016 & 23,910 & 177 & 10,916 & & 174 \\
\hline
\end{tabular}

Source: TURKSTAT, 2017 (www.tuik.gov.tr)

Table 2. Dried-seed grape production in Besni district $(2006=100)$

\begin{tabular}{|c|c|c|c|c|c|c|}
\hline Year & Area (da) & Index & Production (ton) & Index & Yield (kg/da) & Index \\
\hline 2006 & 5,000 & 100 & 1,050 & 100 & 210 & 100 \\
\hline 2007 & 4,500 & 90 & 1,200 & 114 & 267 & 127 \\
\hline 2008 & 5,100 & 102 & 1,197 & 114 & 235 & 112 \\
\hline 2009 & 5,600 & 112 & 1,320 & 126 & 236 & 112 \\
\hline 2010 & 5,600 & 112 & 3,696 & 352 & 660 & 314 \\
\hline 2011 & 5,600 & 112 & 1,120 & 107 & 200 & 95 \\
\hline 2012 & 5,600 & 112 & 3,696 & 352 & 660 & 314 \\
\hline 2013 & 5,700 & 114 & 4,399 & 419 & 772 & 368 \\
\hline 2014 & 5,700 & 114 & 4,275 & 407 & 750 & 357 \\
\hline 2015 & 6,100 & 122 & 4,500 & 429 & 750 & 357 \\
\hline 2016 & 6,100 & 122 & 5,490 & 523 & 900 & 429 \\
\hline
\end{tabular}

Source: TURKSTAT, 2017 (www.tuik.gov.tr) 
Table 3. Organic vegetable production in Turkey $(2005=100)$

\begin{tabular}{c|cccccccc}
\hline Year & Products (pieces) & Index & Producers (person) & Index & Area (ha) & Index & Production (ton) & Index \\
\hline 2005 & 205 & 100 & 14401 & 100 & 203811 & 100 & 421934 & 100 \\
2006 & 203 & 99 & 14256 & 99 & 192789 & 95 & 458095 & 109 \\
2007 & 201 & 98 & 16276 & 113 & 174283 & 86 & 568128 & 135 \\
2008 & 247 & 120 & 14926 & 104 & 166883 & 82 & 530224 & 126 \\
2009 & 212 & 103 & 35565 & 247 & 501641 & 246 & 983715 & 233 \\
2010 & 216 & 105 & 42097 & 292 & 510033 & 250 & 1343737 & 318 \\
2011 & 225 & 110 & 42460 & 295 & 614618 & 302 & 1659543 & 393 \\
2012 & 204 & 100 & 54635 & 379 & 702909 & 345 & 1750127 & 415 \\
2013 & 213 & 104 & 60797 & 422 & 769014 & 377 & 1620387 & 384 \\
2014 & 208 & 101 & 71472 & 496 & 842216 & 413 & 1642235 & 389 \\
2015 & 197 & 96 & 69967 & 486 & 515268 & 253 & 1829291 & 434 \\
2016 & 238 & 116 & 67878 & 471 & 523777 & 257 & 2473600 & 586 \\
2017 & 214 & 104 & 75067 & 521 & 543033 & 266 & 2406606 & 570 \\
2018 & 213 & 104 & 79563 & 552 & 626884 & 308 & 2371612 & 562 \\
\hline
\end{tabular}

Source: TURKSTAT, 2019 (www.tuik.gov.tr)

Table-seed grape

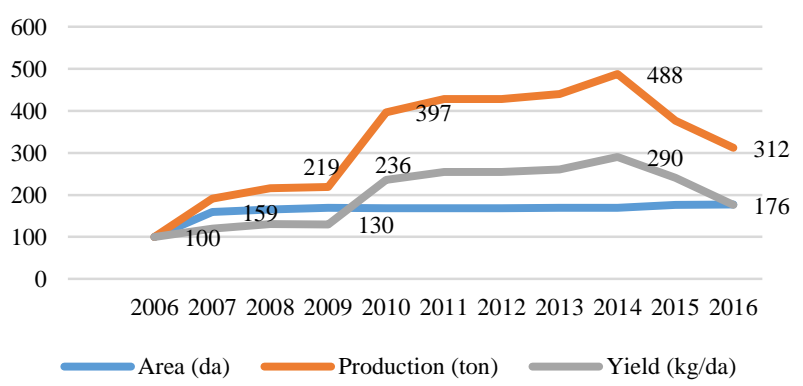

Figure 1. Distribution of table-seed grape production by index values in Besni $(2006=100)$

Organic vegetable production

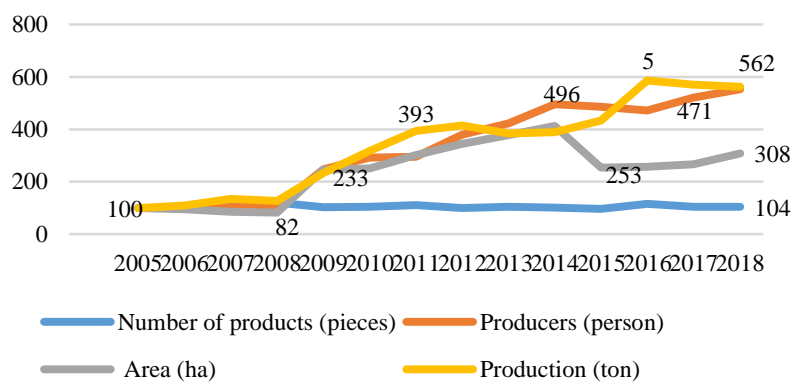

Figure 3. Distribution of index values based on organic vegetable production in Turkey $(2005=100)$

\section{Findings Obtained as a Result of the Research}

Within the scope of the research conducted in the region, 50 producers voluntarily participated were interviewed face to face. According to the findings, it has been determined that organic grape producers in Besni district mostly concentrate in regions such as Çorak, Suvarlı, Pınarbaşı, Çakallı. Approximately 95\% of the producers, who are generally in the middle age group, are individuals between the ages of 30 and 70. Producers growing organic grapes are usually in the 30-80 age range. The average age was determined to be 52 (Figure 4).

Considering the training levels of the producers; it is seen that most of them are at the primary school level. The low level of training of producers causes them to adopt
Dried-seed grapes

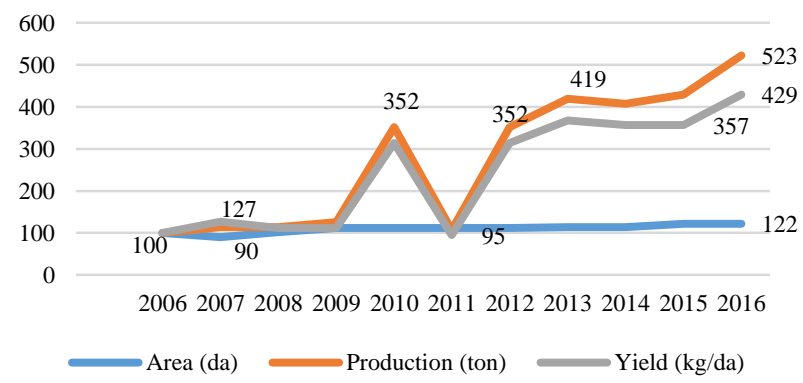

Figure 2. Distribution of dried-seed grape production by index values in Besni district $(2006=100)$

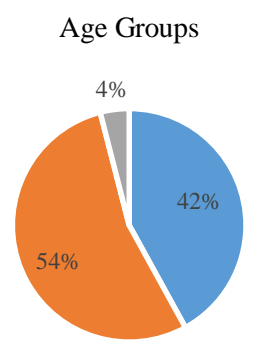

$$
\text { -30-50 age } \quad=51-70 \text { age }=70+
$$

Figure 4. Distribution of producers by age ranges

innovations late. This situation significantly affects both the sustainability of production and product variety (Figure 5).

Considering the distribution of producers according to the number of individuals in the family; While $16 \%$ constitute families of $1-3$ people, $74 \%$ have $4-7$ people and $10 \%$ have 8 or more individuals. The number of individuals in the producers' family is between 2-8 people and on average consists of families of 5 people. Approximately $90 \%$ of the producers participating in the research have more than 10 years of vegetable production experience. The vegetative production experience of the producers varies between 5-65 years and on average 27 years. Also, the vast majority of producers are very experienced in grape growing. It has been determined that the grape-growing 
experience of the producers varied between 5-42 years and the grape growing for an average of 20 years. Organic farming experience of producers varies between 1-6 years. Organic farmers have an average of 3 years of experience in this field. Also, it has been determined that $70 \%$ of the producers have started this activity in the last 3 years.

According to the findings, the vast majority of producers reported that they did not receive any training on grape growing. Only $10 \%$ stated that they received training on this subject. It has been observed that the producers who are not trained about grape cultivation grow with the

Education Status (\%)

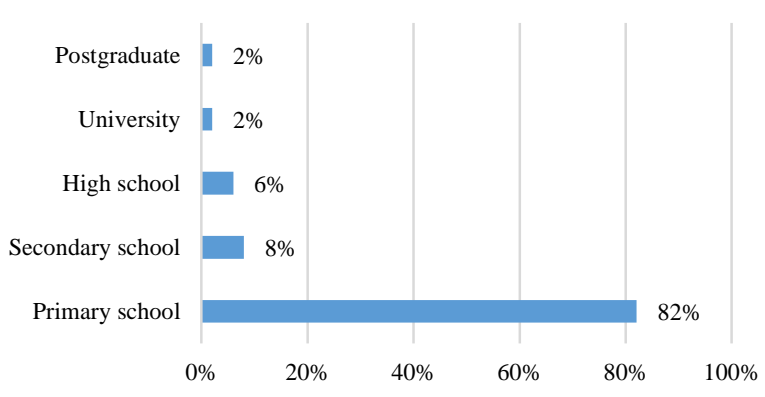

Figure 5. Distribution of producers by educational status

Besides agricultural production; $12 \%$ of producers also operate in non-agricultural professions such as doctors, headmen, workers, and drivers. Most of the producers stated that they did not carry out any activities other than agricultural production. The monthly income of nonagricultural businesses varies between 1,400 $€$ and 10,000 £. It has an average monthly income of 3,950 £.

Organic farmers with computers also have internet access. However, the vast majority of producers stated that they do not own computers and the internet (Table 4). This situation varies depending on the education level and occupational groups.

Table 4. Computer and internet ownership status of producers

\begin{tabular}{c|cc}
\hline Computer & Frequency & $\%$ \\
\hline Available & 4 & 8.0 \\
Non-available & 46 & 92.0 \\
Total & 50 & 100.0 \\
Internet & Frequency & $\%$ \\
Available & 4 & 8.0 \\
Non-available & 46 & 92.0 \\
Total & 50 & 100.0 \\
\hline
\end{tabular}

Producers' reading habits are rather low. While $14 \%$ of the producers regularly read newspapers, $86 \%$ reported that they did not read it occasionally or at all (Figure 6).

Social security is a necessity for everyone while carrying out agricultural activities as in every field. Approximately $70 \%$ of organic grape producers also have social security. Producers take out agricultural insurance to guarantee their products and keep their losses to a minimum. It was determined that $42 \%$ of the producers participating in the study had agricultural insurance regularly and $58 \%$ did not make or renew their insurance. traditional methods learned from the family, as they see from the environment. It was observed that the producers who did not receive training on grape production cultivate as they see from the environment with traditional methods learned from the family. In a study carried out by RoitnerSchobesberger et al. (2008) has revealed that a lack of information on organic farming is a serious problem. Besides, it was determined that $8 \%$ of the producers kept the enterprise's records and recorded the activities they carried out, and $92 \%$ did not keep the records.

Newspaper Reading Habits (\%)

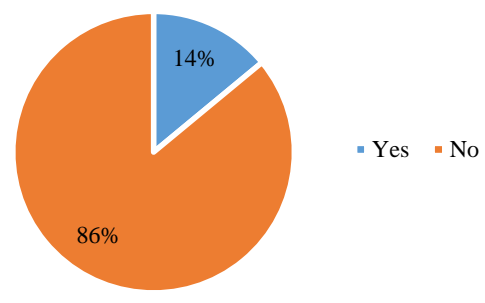

Figure 6. Distribution of producers according to newspaper reading habits $(\%)$

Also, approximately one-third of the producers use loans from Ziraat Bank to purchase tractors and produce grapes.

All of the producers participating in the research receive organic farming support. Also, the producers stated that they benefited from diesel support, fertilizer, animal husbandry, and feed. Remarkably, $80 \%$ of organic farming producers benefit from animal husbandry support. While nearly two-thirds of the grape producers in the region find the support provided insufficiently, one third find it sufficient and $12 \%$ partially sufficient.

Many factors have been influential in the start of organic farming. It has been determined that the producers are aware of the village headmen, the district agriculture directorate, private companies that provide organic farming support through the chamber of agriculture and the agricultural advisor. Education levels of organic farmers in the region differ from each other as well as their level of knowledge. The vast majority of organic farmers find themselves sufficiently knowledgeable. Only $6.1 \%$ stated that they have a low level of knowledge.

The vast majority of the producers stated that they are not members of any organization related to grape growing, only $10 \%$ are members of the Chamber of Agriculture, Agricultural Credit Cooperative, and the Grape Growers Union that they established with their local facilities. Most of the grape varieties produced are Besni grape, Azezi, and Kilis land in the region. There is also a little Kabarcık and A ğ grape production. Approximately $80 \%$ of the product produced is purchased by broker-traders. Producers need to cooperate both during production and marketing. This also contributes to the increase in producer income and the development of the regional economy. Also, as in other agricultural activities, there are problems faced by producers in grape production. In this context, it has been 
determined that almost all of the producers have labor problems. Also, most of the producers have suggested that there are insufficient markets and buyers, low product prices, struggling against diseases and pests, low government support, and $30 \%$ of their regions are not suitable for organic farming and still produce.

In a study carried out by Bahşi and Akça (2019) organic products market can not show sufficient progress, it is because of argued the lack of organic products market in Turkey. In a study carried out by Varoğlu and Turhan (2016) explained the reasons for not adopting organic products in terms of price high, lack of information, lack of advertising, insecurity for organic products and inability to find organic products everywhere.

\section{Conclusion}

The average age of the producers participating in the research is 52 and generally in the middle age group. Besides, the vast majority are low in education. However, Besni grape producers have turned to organic farming because of their state support and their desire to sell their products at a higher price. Also, it has been suggested that organic farming is important for the vital sustainability of all living beings, especially humans. Increasing producer income and environmental sensitivity are among the main reasons for the transition to organic farming. Organic farming contributes to the regional economy. It also prevents migration from rural areas to the city as an agricultural activity. Thus, organic farming supports the region in many areas, directly and indirectly. Producers find the input prices required for carrying out organic farming activities partially higher than conventional agriculture. However, producers argue that organic farming is less expensive than traditional agriculture. Producers state that the use of input is minimal and that organic farming is an inexpensive form of production compared to traditional agriculture. The production problem and the difficulty of accessing the chemicals used by the producers are among the main problems of the producers. Also, the marketing problem arises with these difficulties.

\section{References}

Anonymous, 2017a. Adiyaman Province Agricultural Briefing Report.

Anonymous, 2017b. Crops Statistics Data Network (IVA), Accessed: 10 July 2017.

Anonymous, 2018. Available from: http://www.etoplum.com/ adiyaman-ili-besni-ilcesi-iklimi-hakkinda bilgi.html Accessed: 08 February 2018.
Anonymous, 2019. Control and Certification Institution (ECAS), Available from: http://www.ecas.com.tr/turkiyede-organiktarim, Accessed: 04 July 2019.

Ak İ. 2004. Ecological Agriculture and Livestock, 4th National Animal Science Congress Oral Papers, Volume 1, pp. 490497, Isparta.

Ayla D, Altıntaş D. 2017. A review of organic production and marketing issues, Kastamonu University journal of faculty of Economics and Administrative Sciences, Volume 19, Issue 4.

Bahşi N, Akça A. 2019. A Research on the Determination of Consumers' Perspectives on Organic Agricultural Products: Case Study in Osmaniye and Şanlıurfa Provinces, KSU J. Agric Nat 22(1): 26-34, DOI:10.18016/ ksutarimdoga.vi.443228.

Duran M. 2003. "Grape Study", Foreign Trade Research Service March 2003. Available from:http://www.ito.org.tr/ itoyayin/0007921.pdf/, Accessed:07 November 2015

Kirımhan S. 2005. Organic Farming Systems and Environment, Ankara, Available from: http://bilgihanem.com/uzum-nedir/

Kizilaslan H, Olgun A. 2012. Organic Agriculture and Supports Given to Organic Agriculture in Turkey, Gaziosmanpasa University Journal of Faculty of Agriculture, 29 (1), 1-12.

Merdan K. 2014. The economic analysis of organic agriculture in Turkey: Eastern Black Sea application, Ataturk University, Social Sciences Institute, Department of Economics, Ph.D. Dissertation, Erzurum.

Misır G, Pezikoğlu F. 2016. Organic grape production in Turkey and the world, XII. Agricultural Economics Congress Proceedings Book, 25-27 May 2016, Isparta, pp:1805-1810.

Özbağ BC. 2010. Economic Analysis of Organic Farming in Turkey, Uludag University, Insitute of Natural and Applied Science, Ph.D. Dissertation, Bursa.

Roitner-Schobesberger B, Darnhofer I, Somsook S, Vogl CR 2008. Consumer perceptions oforganic foods in Bangkok, Thailand, Food Policy, Volume 33, pp. 112-121.

Taşkaya B. 2005. Dried grape, Agricultural Economics, and Research Institute Publications, Issue 3, Volume 7, Ankara.

Turhan Ş. 2005. Sustainability in agriculture and organic farming, Journal of Agricultural Economics, Volume 11, Issue 1, İzmir.

TURKSTAT, 2017. Turkish Statistical Institute, Available from: www.tuik.gov.tr, Accessed:15 March 2018.

TURKSTAT, 2019. Turkish Statistical Institute, Available from: www.tuik.gov.tr, Accessed:10 July 2019.

Willer H, Lernoud J (Ed.) 2018. The World of organic agriculture. Statistics and emerging trends 2018. Research Institute of Organic Agriculture (FIBL), Frick, and IFOAM- Organics International, Bonn.

Varoğlu ST, Turhan Ş. 2016. Consumption Trend of Organic Product and Determination of Consumer Profile: A Case Study of Sakarya, Journal of Agricultural Faculty of Gaziosmanpasa University, http://ziraatdergi.gop.edu.tr/, doi:10.13002/jafag923, 33(3): 189-196.

Yercan M. 2003. Agricultural Cooperatives, Ege University Agricultural Application, and Research Center, Farmer Brochure:34. 